\title{
An Analysis on Rose in A Rose for Emily
}

\author{
Yan HUANG \\ School of Foreign Languages, Sichuan University of Science \& Engineering \\ No. 188, University Town, Lingang Economic and Technological Development Zone, \\ Yibin City, Sichuan Province, China
}

Tel: 86-183-9873-0709_E-mail: hyyh812@126.com

Received: June 10, 2019 Accepted: July 13, $2019 \quad$ Published: July 15, 2019

doi: 10.5296/jsss.v6i2.15099 URL: https://doi.org/10.5296/jsss.v6i2.15099

\begin{abstract}
A Rose for Emily is the first published short story of William Faulkner, which talks about a tragic life of an elderly Southern woman Emily Grierson. In the whole story, the none rose does not appear, the only use of the word is an adjective for two times. The "Rose" in the title "A Rose for Emily" attracted a lot of attention. This paper will analyze the rose on two main aspects: the symbolic meaning of rose and who give rose to Emily.
\end{abstract}

Keywords: Rose, Emily

\section{Introduction}

A Rose for Emily is a typical short story by American writer William Faulkner, which was published on the issue of Forum in the April 30, 1930. This story talks about a southern noble woman's tragic life because of the totally changed social system after the civil war. While in the whole story, the none rose does not appear in the story itself, the only use of the word is an adjective for two times. So why did the author still choose "A Rose for Emily" as the title? Specifically, who gave this rose to Emily? To find out this question, on the one hand, it is necessary to figure out what the rose stand for. On the other hand, who would like to give the rose to Emily should be analyzed.

\section{The Symbolic Meaning of Rose}

\subsection{Love}

Rose is a very beautiful flower, which stands for the love and happiness. In this story, however, Emily suffered her whole life lonely and dolefully, having her love only by staying with her lover's corpse. Emily was born a family of the antebellum Southern aristocracy. She 
was tightly controlled by her father in her private life. Her father refused for her to marry. When her father died at Emily's around 30 years old, she was still unmarried. She had to live lonely. The better thing is, without the restriction of her father, Emily could search for true love as she wants.

When Homer Barron, a Northerner, came to her life, Emily did all her best for the "love", without thinking of the hatred between the Southerner and the Northerner just after the Civil War or gossiping among the people in town. Even though Homer said he won't marry, Emily prepared for marriage. The readers can not know what happened between Homer and Emily, she poisoned him to possess the eternal love by staying with Homer's corpse. A woman was so longing for love and was crazy when losing love. On this point, a lack of love can be one of the most possible reason for her tragedy. If she can have love, can she have a happier life? A rose for Emily, for the love she deserved to have.

\subsection{Salute}

Emily was a martyr for the traditional southern system. As it is said in the novel: "Alive, Miss Emily had been a tradition, a duty, and a care." (Faulkner, 229) She fight with the whole new system solely, by her house, her refusal to pay taxes. "Only Miss Emily's house was left, lifting its stubborn and coquettish decay above the cotton wagons and the gasoline pumps-an eyesore among eyesores." (Faulkner, 229) After the Civil War, she continued to live as if in the past. For her bravery, for her persistent, for her suffering, a rose for her was regarded as a salute to show the sympathy for her. Faulkner described the title "A Rose For Emily" as an allegorical title: this woman had undergone a great tragedy, and for this Faulkner pitied her. As a salute, he handed her a rose (wikipedia).

\subsection{Secrecy}

According to Greek legends, roses have been portrayed as a gift of secrecy and of confidentiality, known as sub rosa (wikipedia) On this sense, roses mean secrecy. The story begins with the death of Emily, then little by little, her mysterious life was displayed. Until the end of the story, the readers know the secrecy of Emily's mysterious life. The narrator help Emily to keep her secrets until her death, just like a protection to her. The rose to Emily just like a symbol of silence between the narrator and Miss Emily (wikipedia).

\section{Who Would Like to Give the Rose to Emily?}

Based on analyzing the meaning of rose, the person who gave the rose to Emily can be concluded into three groups: William Faulkner the author, the people in town and the readers.

\subsection{The Author}

Faulkner was an offspring of a southern aristocrat. His great-grandfather was said to be the owner of a big manor. When he was young, Faulkner was told about his great-grandfather's achievements a lot. He greatly admired his talents, his boldness and his spirit of pioneer. To him, his great-grandfather was the symbol of the past world and the representative of persistent and dauntless previous pioneer in old south (xiao 5). In his many books, he mentioned his great-grandfather or even took him as the original image of his character. He 
likes to tell about him. While to his father, as the one who made his family declined, he even never mentioned him at all no matter in his books or his speech. Many people said Faulkner had a strong south sense and was proud of his family history (Xiao 2). These factors proved that Faulkner did like the old southern system. He cherished the memory of that world. In the story, Emily is experiencing of losing that world. After the civil war, her world changed totally. In facing to these changes, these women in old south refused to accept this new value entirely. To keep their wholeness, they ignored the changed and changing reality, burring themselves in the isolate world built up by themselves because of incapability of changing the objective world to their needed subjective one (Zhu 85). Emily was one of them, she cuts herself off from time and constructs a room (Burg 388). Faulkner once explained the reason for his choice of $A$ Rose For Emily as the title, as well as his intention with rose:

[The title] was an allegorical title; the meaning was, here was a woman who has had a tragedy, an irrevocable tragedy and nothing could be done about it, and I pitied her and this was a salute ... to a woman you would hand a rose." (Wikipedia)

Faulkner's sympathy and esteem to Emily were presented in his words obviously. Faulkner himself was the admirer of the south. He had successfully adjusted himself to the new world. He had no choice but to get used to it. Emily was the unlucky one who failed to adjust her. She still insisted to what she thought of right. She built up a world in the house that her father left her. Her only "southern" house in the town, her way of treating others, her attitude to tax etc. show her insistence to the old southern world. This kind of insistence may rightly be what Faulkner want to have but can't get. On this point, no matter it's eulogizing or pitying, it's no doubt that Faulkner could be the one who gave Emily the rose.

\subsection{The People in Town}

The next group who could possibly give Emily the rose is the town people. At the beginning of the story, Faulkner classified the people in town into two parts. To Emily's funeral, "the men through a sort of respectful affection for a fallen monument, the women mostly out of curiosity to see the inside of her house". (Faulkner 229). Rose stands for affection, adoration or admiration. Could the male in town can be the ones giving the rose?

The male in town include the new generation and the old one. To the new generation, Emily was a fossil. To the old generation, Emily was a goddess. In the old south, women are described as pure, holy, the best, and the most refined example of their culture (Du 22). Emily was the representative of these women. She was ever the goddess to most men. Thus in the mind of the old male generation, they still respected Emily and still called her Miss Emily. When Emily was a young lady, she had so many wooers, but her father drove away all the young men. Her father may think that none of the young men were quite good enough for Miss Emily and such. Thus, Emily was not only the Goddess for men; what's more, she was an unavailable Goddess. After her father died, Colonel Santoris even made up an excuse to help her in fear of hurting her. To help Emily, Colonel Santoris contemporaries sent their daughters and granddaughters to her. After her death, the very old men, some in their brushed Confederate uniforms believed that they had danced with her and courted her perhaps. They were proud of dancing and counting with Emily. To them, Emily was still the symbol of success, still the Goddess they pursued. So on this point, it's reasonable that they would be 
the ones who give rose to Emily.

\subsection{The Readers}

Emily is the only one who insists on the south system in the town. "She never has her own life, and never controls her fate. She just lives in the world according to the norms and standard formed by tradition and society. She is one of the victims of the southern womanhood." (Du 21) The readers are moved by her bravery, as well as feel sorry for her stubborn. She suffered so much from the social change. In face up to this change, she, who is supposed to be weak and pure and needing protection, tried to hold fast to the last thing in the old system in her own way, refusing to accept the passing of time and even the death. She regarded herself as "a tradition, a duty, and a care, a sort of hereditary obligation upon the town.” (Faulkner 229) Even situation has changed totally, she still didn't forget her noble obligation. She was a martyr of the lost south. Faulkner gave Emily the rose to salute her for her irrevocable tragedy; the readers give her the rose to salute her for her adamancy as well as her suffering.

\section{Conclusion}

As the above analysis, Emily was deserved a rose. There is not any adornment or sunshine in her whole life, let alone the vitality and rosiness represented by rose. No matter it's Faulkner himself, the people living in the same town as Emily, or the readers, they all could be the one who gave her the rose to sympathize Emily's lack of love, to salute her bravery and to pity her to keep her secrets.

\section{Acknowledgements}

My special thanks go to Professor Shi Jian and Professor Ellis Williams of Sichuan University. Their abundant knowledge and patient guidance led me find my interest direction of the field and finally finished this paper with their gentle suggestions.

\section{References}

Burg, J. (2000). Using Constraint Logic Programming to Analyze the Chronology in "A Rose for Emily". Computers and the Humanities (pp. 377-392). Netherlands: Kluwer Academic Publishers. https://doi.org/10.1023/A:1026594916008

Du, F. (2007). Who Makes a Devil out of a Fair Lady? -An Analysis of the Social Causes of Emily's Tragedy in "A Rose for Emily". Canadian social Science, 3(4), 18-24.

Faulkner, W. (2011). A Rose for Emily (pp. 229-236).

Xiao, M. H. (1999). WILLIAM FAULKNER Soul in Fury. Sichuan: Sichuan People Press.

Zhu, Z. W. (2004). A Study of William Faulkner's Novel Creation from a Perspective of Aesthetics. Shanghai: Shanghai Century Publishing (Group) Co. Ltd.

\section{Copyright Disclaimer}

Copyright for this article is retained by the author(s), with first publication rights granted to the journal.

This is an open-access article distributed under the terms and conditions of the Creative Commons Attribution license (http://creativecommons.org/licenses/by/3.0/). 